Rafał GAŁEK ${ }^{1}$

\title{
Zastosowanie algorytmów inteligencji obliczeniowej do wyznaczania właściwości cieplnych materiałów
}

\begin{abstract}
$\mathrm{W}$ artykule przedstawiono zasadę pomiaru współczynnika przewodzenia ciepła k oraz dyfuzyjności cieplnej a w stanie periodycznie ustalonym (quasi-ustalonym) z zastosowaniem optymalizacji wykorzystującej algorytm inteligencji obliczeniowej do rozwiązania zagadnienia odwrotnego. Prowadzenie pomiarów w stanie periodycznie ustalonym będącym szczególnym przypadkiem stanu nieustalonego pozwala na uwzględnienie zjawisk akumulacji ciepła, a przy tym umożliwia opis przebiegu czasowego wartości temperatury przy użyciu tylko dwóch wielkości: amplitudy $T_{A}$ i kąta przesunięcia fazowego $\varphi_{T}$ oscylacji sygnału temperaturowego. Analiza jednowymiarowego przypadku przewodzenia ciepła w tym stanie posłużyła do wyznaczenia zależności pomiędzy $T_{A}$ oraz $\varphi T$, a szukanymi wartościami właściwości cieplnych materiału $k$ i $a$. Procedura okazała się odpowiednia do dokładnego odtworzenia wartości przewodności i dyfuzyjności cieplnej w perspektywie nieprzekraczającej 100 generacji działania algorytmu genetycznego przy populacji liczącej 50 osobników. Zaproponowana metoda charakteryzuje się prostą konfiguracją eksperymentalną oraz stosunkowo niską wrażliwością wielkości mierzonych bezpośrednio na błędy systematyczne, jednak dopiero weryfikacja eksperymentalna pozwoli ocenić jej praktyczną przydatność.
\end{abstract}

Słowa kluczowe: pomiary cieplne, przewodność cieplna, dyfuzyjność cieplna, optymalizacja, algorytm genetyczny, stan periodycznie ustalony

\section{Wstęp}

Znajomość właściwości cieplnych materiałów, takich jak przewodność czy dyfuzyjność cieplna, jest niezbędna do poprawnego projektowania urządzeń energetycznych, jak również konstrukcji podlegających znaczącym obciążeniom termicznym. Chociaż dla standardowych materiałów dane takie są na ogół dostępne $\mathrm{w}$ postaci kart katalogowych producenta, bądź zawarte w międzynarodowych normach, mają one niekiedy postać wartości zgrubnych lub zakresu, w którym znajduje się rzeczywista wartość przewodności czy dyfuzyjności cieplnej. W zastosowaniach laboratoryjnych, prototypach lub urządzeniach wykorzystujących materiały nietypowe dokładność taka może być niewystarczająca, co pociąga za sobą konieczność pomiaru właściwości cieplnych. O ile w stanie ustalonym przewodzenie ciepła uzależnione jest jedynie od wartości współczynnika przewodzenia ciepła $k$, o tyle w stanie nieustalonym do pełnej charak-

\footnotetext{
${ }^{1}$ Autor do korespondencji/corresponding author: Rafał Gałek, Politechnika Rzeszowska, al. Powstańców Warszawy 8, 35-959 Rzeszów, tel.: (17) 7432382, e-mail: rafalgalek@ prz.edu.pl
} 
terystyki cieplnej materiału wymagana jest dodatkowo znajomość dyfuzyjności cieplnej $a$. W związku z tym za szczególnie przydatną w praktyce należałoby uznać metodę pozwalającą na pomiar obu tych wielkości jednocześnie.

Spośród technik pomiarowych posiadających takie możliwości najpopularniejszą i najszerzej stosowana jest laserowa metoda impulsowa (ang. Laser Flash Analysis, LFA). Chociaż zwykle traktowana jest jako sposób pomiaru dyfuzyjności cieplnej, już jedna z pierwszych dotyczących jej publikacji [1] przewidywała możliwość równoczesnego pomiaru przewodności cieplnej. Metoda polega na impulsowym ogrzewaniu jednej strony próbki badanego materiału i rejestracji przebiegu czasowego temperatury po stronie przeciwnej. Z rozwiązania jednowymiarowego równania nieustalonego przewodzenia ciepła dla takiego przypadku wynika, że do określenia wartości dyfuzyjności cieplnej wystarczająca jest znajomość czasu, po którym temperatura mierzona osiągnie połowę swojej wartości maksymalnej, natomiast wyznaczenie przewodności cieplnej wymaga dodatkowo znajomości ilości energii dostarczonej do próbki. Laserowa metoda impulsowa ze względu na stosunkowo prostą konfigurację eksperymentalną i jasno zdefiniowane założenia zyskała znaczną popularność i do dnia dzisiejszego jest przedmiotem modyfikacji oraz ulepszeń, a także międzynarodowej standaryzacji. Etapy rozwoju tej metody podsumowano m.in. w [2] zwracając uwagę na sposób uwzględniania odstępstw rzeczywistych eksperymentów od modelu teoretycznego w zakresie strat ciepła, skończonej długości impulsu oraz niejednorodnego ogrzewania próbki.

Inną szeroko stosowaną metodą równoczesnego pomiaru wartości dyfuzyjności i przewodności cieplnej jest procedura wykorzystująca rozwiązanie analityczne nieustalonego przewodzenia ciepła wokół nieskończenie długiego źródła powierzchniowego (ang. Transient Hot Strip, THS) zaproponowana w [3]. Polega ona na umieszczeniu cienkiej taśmy grzewczej w badanym ośrodku i wywołaniu stanu nieustalonego przewodzenia ciepła poprzez zasilenie jej prądem elektrycznym o stabilizowanym natężeniu. Napięcie zasilania taśmy zmienia się $\mathrm{z}$ powodu zmiany jej rezystancji wywołanej $\mathrm{z}$ kolei zmianą temperatury. W związku z tym możliwe staje się powiązanie przebiegu czasowego spadku napięcia na oporze taśmy z przebiegiem temperatury uzyskanym w wyniku rozwiązania równania przewodzenia ciepła. Parametrami takiej zależności są m.in. szukane wartości współczynników $k$ i $a$. W metodzie tej taśma grzewcza pełni rolę zarówno źródła ciepła jak i czujnika temperatury, co w znacznym stopniu upraszcza układ pomiarowy. Zaznaczyć należy, że metoda THS nie daje zależności pozwalającej wyznaczyć wartość dyfuzyjności cieplnej w sposób jawny. Konieczna jest iteracyjna procedura poszukiwania wartości a spełniającej otrzymane na drodze teoretycznej równanie czyli w istocie rozwiązanie zagadnienia optymalizacji.

Pochodną metody THS jest technika pomiarowa wykorzystująca czujnik zwany „gorącym dyskiem” (hot disk; ang. Transient Plane Source, TPS) zaproponowana przez tego samego autora w [4]. Folia grzewcza zastąpiona została 
przez podwójną spiralę wykonaną z cienkiej warstwy niklu zabezpieczoną po obu stronach folią kaptonową. Zasada pomiaru i analiza danych jest analogiczna jak w metodzie THS, a więc obejmuje iteracyjne poszukiwanie wartości dyfuzyjności cieplnej $a$. W pracy [5] procedurę tę zmodyfikowano uwzględniając bezwładność cieplną czujnika i nieuniknione opóźnienia wprowadzane przez aparaturę pomiarową, co powodowało konieczność optymalizacji dwuparametrowej (dyfuzyjność cieplna $a$ oraz stała czasowa $t_{\mathrm{c}}$ ). Metoda TPS zyskała popularność dzięki komercyjnej dostępności gotowych czujników, a nawet została rekomendowana jako międzynarodowy standard badania właściwości cieplnych tworzyw sztucznych [6].

Do rzadziej stosowanych metod jednoczesnego pomiaru przewodności i dyfuzyjności cieplnej należy technika kalorymetrii radiacyjnej przedstawiona m.in. w [7]. W metodzie tej wyznaczenie wartości $k$ oraz $a$ odbywa się na podstawie bilansu energetycznego próbki materiału, która wymienia ciepło z powierzchnią grzałki oraz ściankami komory próżniowej jedynie drogą promieniowania. Pomiar prowadzony jest w warunkach nieustalonych przy stałym niewielkim tempie chłodzenia lub ogrzewania. Metoda ta nie jest powszechnie stosowana głównie ze względu na trudności eksperymentalne związane z wymaganiem prowadzenia pomiaru w warunkach próżni, która konieczna jest dla wyeliminowania wpływu konwekcji na wymianę ciepła.

Wspomnieć należy również o modyfikacji metody różnicowej kalorymetrii skaningowej (ang. Differential Scanning Calorimetry, DSC), która co prawda nie pozwala na wyznaczenie wartości $k$ i $a$ w czasie jednego pomiaru, możliwe jest to natomiast przy zastosowaniu identycznej konfiguracji eksperymentalnej dla badanych kolejno dwóch próbek materiału o różnej grubości. Modyfikacja metody polega na wprowadzeniu periodycznych oscylacji gęstości strumienia ciepła dostarczanego do próbki, co skutkuje oscylacją jej temperatury (ang. Modulated Temperature Differential Scanning Calorimetry, MTDSC). Pojemność cieplną próbki wyznaczyć można jako stosunek amplitud obu tych sygnałów [8], co przy znajomości jej masy pozwala na znalezienie wartości ciepła właściwego badanego materiału. Jest to typowe zastosowanie metody MTDSC, w którym próbka powinna być stosunkowo cienka i umieszczona w zamkniętej komorze pomiarowej. W pracy [9] zaproponowano technikę pomiaru przewodności cieplnej w konfiguracji eksperymentalnej charakterystycznej dla metody MTDSC, wykorzystującej jednak próbkę o większej grubości umieszczoną w komorze otwartej, dzięki czemu modulowana gęstość strumienia ciepła stanowi warunek brzegowy tylko na jednej z powierzchni materiału. Pozwala to na wyznaczenie tzw. pozornej pojemności cieplnej, z której obliczyć można wartość współczynnika przewodzenia ciepła $k$ znając wyznaczone wcześniej ciepło właściwe, wymiary próbki oraz okres oscylacji. Metoda znajduje zastosowanie głównie w badaniu właściwości izolatorów cieplnych, co potwierdzono opracowanym na podstawie [9] standardem ASTM E1952 - 11 Standard Test Method for Thermal 
Conductivity and Thermal Diffusivity by Modulated Temperature Differential Scanning Calorimetry.

$\mathrm{Z}$ punktu widzenia teorii wymiany ciepła pole temperatury występujące w przestrzeni jest skutkiem zjawiska przepływu ciepła, natomiast za jego przyczyny uznać należy warunki brzegowe oraz początkowe, geometrię domeny, a także właściwości cieplne wypełniającej ją substancji. Klasyczne sformułowanie problemu wymiany ciepła zwane zagadnieniem prostym obejmuje poszukiwanie skutków zjawiska przy znanych jego przyczynach, a więc obliczenie pola temperatury $\mathrm{w}$ całkowicie scharakteryzowanej domenie. $\mathrm{Z}$ drugiej strony problem poszukiwania warunków brzegowych, początkowych lub właściwości materiału na podstawie znanej temperatury w całej domenie lub jej części nazywany jest zagadnieniem odwrotnym. Dla problemów tego typu nie ma zwykle dowodu, że jakiekolwiek ich rozwiązanie jest jednoznaczne, a dodatkowe trudności sprawia fakt ich złego uwarunkowania, co oznacza, że niewielkie zmiany wielkości wejściowych powodować mogą znaczne zaburzenia wielkości wyjściowych [10]. Przeważająca większość zagadnień odwrotnych nie posiada rozwiązania analitycznego, dlatego też konieczne jest zastosowanie pewnego rodzaju algorytmu poszukiwania takich wartości parametrów, aby spełnione były założenia, które otrzymać można na drodze teoretycznej. Optymalizacja taka stosowana jest m.in. w przypadku wspomnianych metod THS i TPS.

Rozwiązanie zagadnienia odwrotnego na drodze optymalizacji w najbardziej ogólnym sformułowaniu polega na iteracyjnym rozwiązywaniu stowarzyszonego zagadnienia prostego przy założonych z góry wartościach parametrów poszukiwanych i porównywanie jego wyników z daną informacją o skutku zjawiska (np. wartości temperatury) w całej domenie lub jej części. Porównanie takie jest następnie podstawą do modyfikacji założonych wartości parametrów poszukiwanych, które służą za dane wejściowe w zagadnieniu prostym dla kolejnej iteracji. Przykładem takiej sytuacji może być problem, w którym znana jest geometria domeny oraz warunki brzegowe i początkowe, a poszukiwane są wartości właściwości cieplnych materiału domeny. Zagadnienie odwrotne jest możliwe do rozwiązania, jeżeli dodatkowo dane są wartości temperatury w jednym lub kilku punktach badanej próbki. Optymalizacja rozpoczyna się od losowego lub popartego praktycznymi przesłankami założenia wartości właściwości cieplnych, rozwiązania zagadnienia prostego, a więc wyznaczenia pola temperatury i porównania go z wartościami temperatury w punktach, w których jest ona znana. Konieczne jest tutaj wprowadzenie pewnej ilościowej miary różnicy pomiędzy wynikami uzyskanymi na podstawie rozwiązania zagadnienia prostego, a wartościami zaobserwowanymi w rzeczywistości. Zależność pozwalającą na obliczenie takiej różnicy nazywa się funkcją kosztu i w najprostszym przypadku może ona mieć postać sumy kwadratów różnic pomiędzy wartościami obliczonymi, a zaobserwowanymi [11], jakkolwiek niekiedy celowe jest rozszerzenie jej o dodatkowe składniki. Jako przykład można wskazać człon regularyzacyjny pozwalający uniknąć oscylacji rozwiązania lub człon karny 
eliminujący niefizyczne wartości parametrów [12]. Kolejnym krokiem jest modyfikacja wartości poszukiwanych wielkości w oparciu o wartość funkcji kosztu. Jest to prawdopodobnie najważniejszy etap procedury optymalizacji, a z pewnością czynnik wyróżniający poszczególne algorytmy. Nowy zestaw parametrów służy następnie do rozwiązania zagadnienia prostego w kolejnej iteracji, w której ponownie obliczana jest wartość funkcji kosztu. Jeżeli problem możliwy jest do rozwiązania przy użyciu zastosowanego algorytmu, wartość ta powinna maleć $w$ kolejnych iteracjach osiągając $w$ końcu próg pozwalający na uznanie ostatniego zestawu parametrów wejściowych za rozwiązanie zagadnienia odwrotnego. W przypadku, gdy określenie wartości progowej funkcji kosztu jest utrudnione, za kryterium przerwania iteracji służyć może ich maksymalna dopuszczalna liczba lub liczba iteracji bez wyraźnego spadku wartości funkcji kosztu.

Algorytmy optymalizacji podzielić można ze względu na sposób, w jaki wartości poszukiwanych parametrów modyfikowane są w kolejnych iteracjach. W metodach gradientowych, do których należą algorytmy Levenberga-Marquardta, Gaussa-Newtona, Box-Kanemasu, gradientu sprzężonego czy najszybszego spadku odbywa się to w oparciu o wartości pochodnych funkcji celu względem parametrów wejściowych. Do zalet tych metod należą usystematyzowane podstawy teoretyczne i szybka zbieżność do minimum funkcji kosztu. Minimum to jest jednak w ich przypadku lokalne [13] i najbliższe wartościom parametrów założonych z góry w pierwszej iteracji spośród wszystkich minimów multimodalnej funkcji kosztu. Możliwość uzyskania rozwiązania globalnego jest więc uzależniona od jakości pierwszego założenia. Metody gradientowe nie są ponadto odpowiednie do rozwiązywania zagadnień, w których wartości poszukiwanych parametrów są wzajemnie skorelowane [14].

Techniki optymalizacji wykorzystujące przyjętą arbitralnie strategię niezwiązaną z pochodną funkcji kosztu do modyfikacji parametrów wejściowych w poszczególnych iteracjach nazywane są metodami heurystycznymi. Zaliczają się do nich algorytmy przeszukiwania stochastycznego (np. przeszukiwanie lokalne), a także metody inteligencji obliczeniowej takie jak algorytmy genetyczne (ang. Genetic Algorithm, GA) czy optymalizacja rojem cząsteczek (ang. Particle Swarm Optimization, PSO). Chociaż nie gwarantują one znalezienia rozwiązania optymalnego i są znacznie bardziej kosztowne obliczeniowo od metod gradientowych [13], niektóre $\mathrm{z}$ ich zalet sprawiają, że w wielu przypadkach stanowią dla nich wartościową alternatywę. Ze względu na swoją stochastyczną naturę GA oraz PSO są w stanie wykonać przeszukiwanie globalne bez ryzyka utknięcia w lokalnym minimum multimodalnej funkcji kosztu. Ponieważ obie metody bazują na populacji rozwiązań inicjowanej losowo, nie jest wymagane początkowe założenie wartości poszukiwanych parametrów. Nie stanowi dla nich przeszkody wzajemna korelacja wartości tych parametrów, a ponadto nie narzucają praktycznie żadnych ograniczeń w zakresie matematycznego sformułowania problemu optymalizacji. 
Powyższe zalety powodowały w ostatnich latach rosnące zainteresowanie metodami inteligencji obliczeniowej jako sposobem rozwiązywania zagadnień odwrotnych wymiany ciepła. Obszerny przegląd zastosowań algorytmów genetycznych w tego typu problemach zaprezentowano w [15]. W pracy [13] GA został zastosowany do identyfikacji zależnej od temperatury przewodności cieplnej w kierunku równoległym i prostopadłym do włókien materiału kompozytowego, a także jego dyfuzyjności cieplnej. Podobny materiał badany był przy użyciu algorytmu genetycznego w [16], gdzie dodatkowo wyznaczono właściwości radiacyjne materiału takie jak współczynnik ekstynkcji i albedo rozpraszania. W pracy tej wykorzystano GA również na etapie projektowania eksperymentu. Przestrzenną zmienność przewodności cieplnej materiałów niejednorodnych badano przy użyciu algorytmu genetycznego w [17] z wykorzystaniem metody elementów brzegowych do rozwiązania zagadnienia prostego. Wyznaczony przy użyciu GA przestrzenny rozkład wartości przewodności cieplnej posłużył do identyfikacji niejednorodności materiału [18]. Temperaturową zależność przewodności cieplnej badano w pracach [10] i [19]. W pierwszej z nich efektywność algorytmu genetycznego porównano z efektywnością sieci neuronowej w rozwiązaniu tego samego problemu, natomiast w drugiej przystosowano GA do potrzeb optymalizacji wielokryterialnej. Algorytmy genetyczne zastosowano do rozwiązywania zagadnień odwrotnych wymiany ciepła mających na celu identyfikację warunków brzegowych w pracach [20-22]. Optymalizacja rojem cząsteczek posłużyła do wyznaczenia zależnej od temperatury pojemności cieplnej autorom pracy [23] natomiast w [24] została wykorzystana do identyfikacji zmiennej w czasie gęstości strumienia ciepła.

Niniejszy artykuł prezentuje koncepcję prostej eksperymentalnie metody pozwalającej na jednoczesny pomiar wartości przewodności cieplnej $k$ oraz dyfuzyjności cieplnej a ciała stałego w warunkach periodycznie ustalonej wymiany ciepła. Przy znanej grubości próbki oraz amplitudzie i częstotliwości sygnału wymuszającego $\mathrm{w}$ postaci modulowanej gęstości strumienia ciepła wymagany jest jedynie pomiar amplitudy $T_{\mathrm{A}}$ i przesunięcia fazowego $\varphi_{\mathrm{T}}$ sygnału temperatury na powierzchni materiału. Konieczna dla znalezienia poszukiwanych wielkości dwuparametrowa optymalizacja jest realizowana przy pomocy jednej z podstawowych implementacji algorytmu genetycznego.

\section{Sformułowanie problemu}

Stan periodycznie ustalony jest szczególnym przypadkiem stanu nieustalonej wymiany ciepła, w którym wartość temperatury podlega periodycznym oscylacjom o stałej w czasie amplitudzie, fazie i częstotliwości. Podobnie stała w czasie jest wartość średnia temperatury. Zaletą pomiarów w stanie periodycznie ustalonym jest fakt, że umożliwiają one uwzględnienie zjawiska akumulacji ciepła i parametrów z nim związanych jak np. dyfuzyjność cieplna, a jednocześnie pozwalają na stosunkowo prosty opis przebiegu zmienności temperatury 
w czasie wykorzystujący głównie dwie wielkości - amplitudę i kąt przesunięcia fazowego sygnału temperatury. Wykorzystanie pomiarów w stanie periodycznie ustalonym do wyznaczenia właściwości cieplnych materiałów, a także warunków brzegowych zaproponowano m.in. w [25]. Wartość temperatury w tak zdefiniowanym stanie zapisać można jako:

$$
T=T_{\mathrm{m}}+\tilde{T} \mathrm{e}^{\mathrm{i} \omega t}
$$

gdzie: $T_{\mathrm{m}}$ - wartość średnia temperatury,

$\omega$ - częstotliwość kątowa oscylacji,

$t$ - czas,

$\tilde{T}$ - temperatura zespolona.

Wartość temperatury zespolonej interpretować należy jako fazor czyli zespoloną amplitudę sygnału temperaturowego:

$$
\tilde{T}=T_{\mathrm{A}} \mathrm{e}^{\mathrm{i} \varphi_{\mathrm{T}}}
$$

gdzie: $T_{\mathrm{A}}$ - amplituda oscylacji sygnału temperatury (liczba rzeczywista),

$\varphi_{\mathrm{T}}$ - kąt przesunięcia fazowego sygnału temperatury.

Uzyskanie stanu periodycznie ustalonego przewodzenia ciepła wymaga, wymuszenia oscylacji temperatury przy pomocy modulowanej gęstości strumienia ciepła na jednej z powierzchni badanej próbki. Próbka badanego materiału w postaci płytki lub dysku musi być więc po stronie A równomiernie ogrzewana strumieniem ciepła o periodycznie oscylującej gęstości. Ponieważ zrealizowanie oscylacji takiego warunku brzegowego wokół wartości zerowej (naprzemienne ogrzewanie $\mathrm{i}$ chłodzenie) byłoby kłopotliwe $\mathrm{z}$ praktycznego punktu widzenia, korzystniej jest wymusić oscylacje temperatury poprzez naprzemienne włączanie i wyłączanie ogrzewania ze stałą częstotliwością. Wartość średnia gęstości strumienia ciepła będzie wówczas równa amplitudzie jej oscylacji, a ta z kolei połowie maksymalnej wartości osiąganej w stanie włączonym:

$$
\dot{q}_{\mathrm{A}}=\dot{q}_{\mathrm{Aamp}}+\tilde{q}_{\mathrm{A}} \mathrm{e}^{\mathrm{i} \omega t}
$$

gdzie: $\dot{q}_{\text {Aamp }}$ - amplituda oscylacji gęstości strumienia ciepła,

$\tilde{q}_{\mathrm{A}}$ - amplituda zespolona oscylacji gęstości strumienia ciepła.

Analogicznie jak w przypadku temperatury, zespoloną amplitudę gęstości strumienia ciepła zapisać można jako:

$$
\tilde{q}_{\mathrm{A}}=\dot{q}_{\text {Aamp }} \mathrm{e}^{\mathrm{i} \varphi_{\mathrm{q}}}
$$


Oscylację gęstości strumienia ciepła traktować należy jako przyczynę zjawiska, natomiast oscylację temperatury jako skutek. Określenie kąta przesunięcia fazowego sygnału temperatury $\varphi_{\mathrm{T}}$ wymaga przyjęcia punktu odniesienia, względem którego takie przesunięcie jest liczone. Korzystne jest w tej sytuacji założenie, że przesunięcie fazowe sygnału gęstości strumienia ciepła $\varphi_{\mathrm{q}}$ jest równe zeru. Wówczas $\varphi_{\mathrm{T}}$ interpretować należy jako przesunięcie fazowe sygnału temperatury względem sygnału gęstości strumienia ciepła, a amplituda $\tilde{q}_{\mathrm{A}}$ będzie posiadać jedynie część rzeczywistą:

$$
\begin{aligned}
& \tilde{q}_{\mathrm{A}}=\dot{q}_{\text {Aamp }} \\
& \dot{q}_{\mathrm{A}}=\dot{q}_{\text {Aamp }}+\dot{q}_{\text {Aamp }} \mathrm{e}^{\mathrm{i} \omega t}
\end{aligned}
$$

Aby możliwe było osiągnięcie stanu periodycznie ustalonego, po stronie B próbka musi być chłodzona. Nie ma tutaj potrzeby wymuszania oscylacji warunku brzegowego, dlatego wystarczające jest chłodzenie stałą w czasie gęstością strumienia ciepła $\dot{q}_{\mathrm{B}}$. Jej wartość powinna być równomierna na całej powierzchni płytki i tak dopasowana do wartości $\dot{q}_{\text {Aamp }}$, aby amplituda oscylacji temperatury $T_{\mathrm{A}}$ była możliwa do zmierzenia dostępnymi środkami. W analizie stanu periodycznie ustalonego nie występuje warunek początkowy. Podczas rzeczywistego eksperymentu jednak próbka będzie mieć na początku pomiaru temperaturę zbliżoną do temperatury otoczenia, a założenia stanu periodycznie ustalonego spełnione będą dopiero po upływie pewnego czasu od przyłożenia oscylacyjnego warunku brzegowego. $\mathrm{Z}$ praktycznego punktu widzenia czas ten powinien być jak najkrótszy, a zależał on będzie od wzajemnej relacji wartości $\dot{q}_{\mathrm{B}}$ i $\dot{q}_{\text {Aamp. }}$ Przykładowy schemat stanowiska pozwalającego na realizację opisanych warunków brzegowych oraz pomiar wielkości koniecznych do wykonania obliczeń przedstawia rysunek 1 .

Dla konfiguracji eksperymentalnej zrealizowanej w opisany powyżej sposób uznać można, że w pewnej odległości od powierzchni bocznych próbki przewodzenie ciepła w jej objętości opisane może być z wystarczającą dokładnością jednowymiarowym równaniem przewodzenia ciepła w stanie nieustalonym:

$$
\frac{\partial^{2} T}{\partial x^{2}}=\frac{1}{a} \frac{\partial T}{\partial t}
$$

gdzie: $a$ - dyfuzyjność cieplna,

$x$ - współrzędna na kierunku prostopadłym do powierzchni ogrzewanej i chłodzonej. 


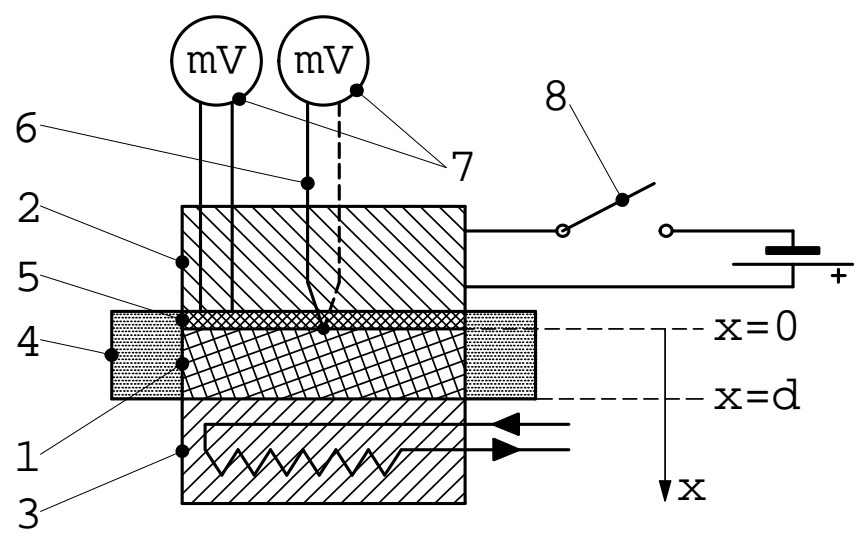

Rys. 1. Przykładowy schemat stanowiska pomiarowego: 1 próbka, 2 - grzałka oporowa, 3 - chłodnica wodna, 4 - izolacja, 5 miernik gęstości strumienia ciepła, 6 -termoelement, 7 miliwoltomierz, 8 - wyłącznik

Fig. 1. Exemplary schematic of the measuring position: 1 -sample, 2 - resistance heater, 3 - water cooler, 4 -insulation, 5 - heat flux measuring instrument, 6 - thermocouple, 7 - millivoltmeter, 8 - switch

Wstawiając równanie przebiegu zmienności temperatury $\mathrm{w}$ stanie periodycznie ustalonym (1) do równania (7) otrzymuje się:

$$
\frac{\partial^{2} T_{\mathrm{m}}}{\partial x^{2}}+\frac{\partial^{2} \tilde{T}}{\partial x^{2}} \mathrm{e}^{\mathrm{i} \omega t}=\frac{1}{a} \frac{\partial T_{\mathrm{m}}}{\partial t}+\frac{\mathrm{i} \omega}{a} \tilde{T} \mathrm{e}^{\mathrm{i} \omega t}
$$

W stanie periodycznie ustalonym wartość średnia temperatury jest z założenia stała w czasie:

$$
\frac{\partial T_{\mathrm{m}}}{\partial t}=0
$$

Równanie (8) posiada zarówno składniki zależne jak i niezależne od czasu i mogą one być według tego kryterium rozdzielone na dwa osobne równania [26]:

$$
\begin{aligned}
& \frac{\mathrm{d}^{2} T_{\mathrm{m}}}{\mathrm{d} x^{2}}=0 \\
& \frac{\mathrm{d}^{2} \tilde{T}}{\mathrm{~d} x^{2}}-\frac{\mathrm{i} \omega}{a} \tilde{T}=0
\end{aligned}
$$


Rozwiązaniem równania (11) jest funkcja o wartościach zespolonych postaci:

$$
\tilde{T}=-C_{1} \sin \left[\left(\frac{1}{2}-\frac{1}{2} \mathrm{i}\right) \sqrt{\frac{2 \omega}{a}} x\right]+C_{2} \cos \left[\left(\frac{1}{2}-\frac{1}{2} i\right) \sqrt{\frac{2 \omega}{a}} x\right]
$$

$\mathrm{Z}$ równania (12) wynika, że temperatura zmierzona po stronie ogrzewanej próbki $(x=0)$ będzie co do wartości równa stałej całkowania $C_{2}$, która zależeć musi między innymi od szukanych wartości przewodności cieplnej $k$ oraz dyfuzyjności cieplnej $a$. Znając więc wartość amplitudy oscylacji temperatury po stronie ogrzewanej $T_{\mathrm{A}}$ oraz kąt jej przesunięcia fazowego $\varphi_{\mathrm{T}}$ względem sygnału modulowanej gęstości strumienia ciepła, można na drodze optymalizacji znaleźć takie wartości $k$ oraz $a$, aby spełniona była równość:

$$
\left.\tilde{T}\right|_{x=0}=C_{2}
$$

Konieczność pomiaru temperatury po stronie występowania oscylacyjnego warunku brzegowego stanowić może pewną trudność eksperymentalną, ponieważ powierzchnia próbki musi być dostępna zarówno dla elementu grzewczego jak i czujnika temperatury. Konfiguracja taka możliwa jest jednak do zrealizowania nawet $\mathrm{w}$ sposób bezstykowy dzięki ogrzewaniu powierzchni próbki przy pomocy promiennika i pomiarowi temperatury przy użyciu pirometru.

Na wyznaczenie dokładnej postaci zależności stałej $C_{2}$ od szukanych parametrów materiałowych pozwala analiza warunków brzegowych. Po stronie ogrzewanej próbki warunek brzegowy drugiego rodzaju (Neumanna) przyjmie postać:

$$
\begin{aligned}
& -\left.k \frac{\mathrm{d} T}{\mathrm{~d} x}\right|_{x=0}=\dot{q}_{\mathrm{A}} \\
& -\left.k \frac{\mathrm{d} T_{\mathrm{m}}}{\mathrm{d} x}\right|_{x=0}-\left.k \frac{\mathrm{d} \tilde{T}}{\mathrm{~d} x}\right|_{x=0} \mathrm{e}^{\mathrm{i} \omega t}=\dot{q}_{\text {Aamp }}+\dot{q}_{\text {Aamp }} \mathrm{e}^{\mathrm{i} \omega t}
\end{aligned}
$$

Składniki równania (15) można podobnie jak w przypadku równania (8) podzielić na zależne i niezależne od czasu:

$$
\begin{aligned}
& -\left.k \frac{\mathrm{d} T_{\mathrm{m}}}{\mathrm{d} x}\right|_{x=0}=\dot{q}_{\text {Aamp }} \\
& -\left.k \frac{\mathrm{d} \tilde{T}}{\mathrm{~d} x}\right|_{x=0}=\dot{q}_{\text {Aamp }}
\end{aligned}
$$


$\mathrm{Na}$ podstawie równania (12) wartość pochodnej temperatury zespolonej w punkcie $x=0$ będzie równa:

$$
\left.\frac{\mathrm{d} \tilde{T}}{\mathrm{~d} x}\right|_{x=0}=-C_{1}\left(\frac{1}{2}-\frac{1}{2} \mathrm{i}\right) \sqrt{\frac{2 \omega}{a}}
$$

Stałą $C_{1}$ można więc wyznaczyć ze wzoru:

$$
C_{1}=\frac{\dot{q}_{\text {Aamp }}}{k\left(\frac{1}{2}-\frac{1}{2} \mathrm{i}\right) \sqrt{\frac{2 \omega}{a}}}
$$

Analogicznie analizować można warunek brzegowy po stronie chłodzonej próbki:

$$
\begin{aligned}
& -\left.k \frac{\mathrm{d} T}{\mathrm{~d} x}\right|_{x=d}=\dot{q}_{\mathrm{B}} \\
& -\left.k \frac{\mathrm{d} T_{\mathrm{m}}}{\mathrm{d} x}\right|_{x=d}-\left.k \frac{\mathrm{d} \tilde{T}}{\mathrm{~d} x}\right|_{x=d} \mathrm{e}^{\mathrm{i} \omega t}=\dot{q}_{\mathrm{B}} \\
& -\left.k \frac{\mathrm{d} T_{\mathrm{m}}}{\mathrm{d} x}\right|_{x=d}=\dot{q}_{\mathrm{B}} \\
& -\left.k \frac{\mathrm{d} \tilde{T}}{\mathrm{~d} x}\right|_{x=d}=0 \\
& \left.\frac{\mathrm{d} \tilde{T}}{\mathrm{~d} x}\right|_{x=d}=-C_{1}\left(\frac{1}{2}-\frac{1}{2} i\right) \sqrt{\frac{2 \omega}{a}} \cos \left[\left(\frac{1}{2}-\frac{1}{2} i\right) \sqrt{\frac{2 \omega}{a}} d\right]- \\
& C_{2}\left(\frac{1}{2}-\frac{1}{2} i\right) \sqrt{\frac{2 \omega}{a}} \sin \left[\left(\frac{1}{2}-\frac{1}{2} i\right) \sqrt{\frac{2 \omega}{a}} d\right] \\
& C_{2}=-\frac{\operatorname{tg}\left[\left(\frac{1}{2}-\frac{1}{2} i\right) \sqrt{\frac{2 \omega}{a}} d\right]}{\left.C_{1}\right]}
\end{aligned}
$$




$$
C_{2}=-\frac{\dot{q}_{\text {Aamp }}}{k\left(\frac{1}{2}-\frac{1}{2} i\right) \sqrt{\frac{2 \omega}{a}} \operatorname{tg}\left[\left(\frac{1}{2}-\frac{1}{2} i\right) \sqrt{\frac{2 \omega}{a} d}\right]}=\left.\tilde{T}\right|_{x=0}
$$

$\mathrm{Z}$ równania (26) wynika, że przy znajomości wartości amplitudy oscylacji gęstości strumienia ciepła $\dot{q}_{\text {Aamp }}$ oraz jej częstotliwości kątowej $\omega$ (która jest taka sama jak częstotliwość oscylacji temperatury), a także grubości próbki $d$ pomiar amplitudy $T_{\mathrm{A}}$ i przesunięcia fazowego $\varphi_{\mathrm{T}}$ sygnału temperatury po stronie ogrzewanej jest wystarczający do określenia wartości przewodności $k$ i dyfuzyjności cieplnej $a$ materiału próbki. W tym celu należałoby po obu stronach równania (26) dokonać separacji części rzeczywistej i urojonej (lub amplitudy i fazy) liczb zespolonych i porównać je ze sobą otrzymując układ dwóch równań z dwiema niewiadomymi. Podejście takie okazało się jednak niepraktyczne $\mathrm{z}$ uwagi na stosunkowo złożoną postać zależności $C_{2}$ od poszczególnych czynników. Z tego też powodu do znalezienia wartości $k$ oraz $a$ spełniających równanie (26) wykorzystano dwuparametrową optymalizację przy użyciu algorytmu genetycznego. Zwrócić należy przy tym uwagę na fakt, że przy zaproponowanej konfiguracji eksperymentalnej do osiągnięcia wyniku nie jest konieczna znajomość wartości gęstości strumienia ciepła po stronie chłodzonej $\dot{q}_{\mathrm{B}}$, co eliminuje potrzebę jego pomiaru.

Do optymalizacji wartości $k$ oraz $a$ wykorzystano algorytm Waptia dostępny $w$ domenie publicznej na licencji BSD [27]. Jest to implementacja w środowisku LabVIEW algorytmu Pikaia zrealizowanego oryginalnie w języku Fortran-77 [28]. Działanie algorytmu polega na poszukiwaniu zbioru parametrów wejściowych, który maksymalizuje wartość zdefiniowanej przez użytkownika funkcji dopasowania. Chociaż implementacja obejmuje raczej podstawową wersję algorytmu genetycznego, możliwa jest modyfikacja sposobu jego działania w zakresie planu reprodukcyjnego populacji (zastępowalności pokoleń) czy zachowania dynamicznie dostosowywanego prawdopodobieństwa mutacji.

Algorytm Waptia wykorzystuje kodowanie rzeczywiste tzn. chromosom stanowi sekwencję genów, z których każdy przyjmuje wartość liczby naturalnej z zakresu $0 \div 9$. Wybierając długość chromosomu można więc w prosty sposób określić ilość cyfr znaczących w otrzymanym rozwiązaniu. W każdym pokoleniu osobniki przeznaczone do krzyżowania wybierane są przy pomocy metody koła ruletki. Krzyżowanie odbywa się jednopunktowo tzn. genotypy rodziców dzielone są na losowo wybranym genie, a uzyskane w ten sposób fragmenty pochodzące od obojga rodziców służą do budowy genotypów potomstwa. Również operator mutacji ma charakter jednopunktowy: losowo wybrany gen w chromosomie zamieniany jest na losową liczbę naturalną z zakresu $0 \div 9$.

$\mathrm{Z}$ punktu widzenia użytkownika kluczowym wymaganiem dla poprawnego działania algorytmu jest zdefiniowanie funkcji dopasowania. Jakkolwiek Waptia efektywnie maksymalizuje tę funkcję nie nakładając dodatkowych wymagań 
dotyczących granic jej zbioru wartości, dobrą praktyką jest skonstruowanie jej w taki sposób, aby wartość 0 oznaczała minimalne dopasowanie, natomiast wartość 1 dopasowanie maksymalne. W rozważanym przypadku założenie takie spełnia funkcja zdefiniowana jako:

$$
F=1-\frac{R M S E}{R M S E_{\max }}
$$

RMSE jest średnią kwadratową różnic części rzeczywistych i urojonych wartości temperatury zespolonej w punkcie $x=0$ otrzymanych z pomiaru oraz z zastosowania wzoru (26) dla testowanego zestawu wartości $k$ i $a$ :

$$
R M S E=\sqrt{\frac{\left(\operatorname{Re}\left(\tilde{T}_{\text {ocalc }}-\tilde{T}_{\text {omeas }}\right)\right)^{2}+\left(\operatorname{Im}\left(\tilde{T}_{\text {ocalc }}-\tilde{T}_{0 \text { meas }}\right)\right)^{2}}{2}}
$$

gdzie: $\tilde{T}_{0 \text { calc }}$ - temperatura zespolona w punkcie $x=0$ dla testowego zestawu $k$ i $a$ obliczona ze wzoru (26),

$\tilde{T}_{0 \text { meas }}$ - temperatura zespolona zmierzona w punkcie $x=0$.

Dla działania algorytmu wymagane jest określenie zakresu poszukiwań czyli maksymalnych i minimalnych wartości, w granicach których znajdują się najprawdopodobniej rzeczywiste wartości szukanych parametrów. Wstępna analiza zależności $R M S E$ od $k$ i $a$ wykazała, że maksymalnych wartości różnicy średniokwadratowej spodziewać się należy w skrajnych punktach (narożach) dziedziny poszukiwań. Wielkość $R M S E_{\max }$, wymaganą do znormalizowania wartości funkcji dopasowania do zakresu $\langle 0,1\rangle$, można na tej podstawie zdefiniować jako:

$$
R M S E_{\max }=\max \left(\begin{array}{l}
R M S E\left(k_{\min }, a_{\min }\right), R M S E\left(k_{\min }, a_{\max }\right), \\
R M S E\left(k_{\max }, a_{\min }\right), \operatorname{RMSE}\left(k_{\max }, a_{\max }\right)
\end{array}\right)
$$

gdzie do obliczenia wartości $\operatorname{RMSE}(k, a)$ wykorzystywane są kolejno kombinacje punktów skrajnych zakresu poszukiwań.

Rysunek 2 przedstawia zależność wartości zdefiniowanej w powyższy sposób funkcji dopasowania od wartości poszukiwanych parametrów $k$ i $a$. Widoczna jest stosunkowo silna zależność $F$ od przewodności cieplnej $k$ i znacznie słabsza zależność od dyfuzyjności cieplnej $a$. Powoduje to, że szukane maksimum nie jest wystarczająco wyraźne, tzn. istnieje wiele wartości dyfuzyjności cieplnej, dla których funkcja dopasowania zbliża się do jedności. Spodziewać się należy, że takie uwarunkowanie skutkować będzie mniejszą dokładnością wyznaczania $a$ niż będzie to możliwe w przypadku przewodności cieplnej $k$. 


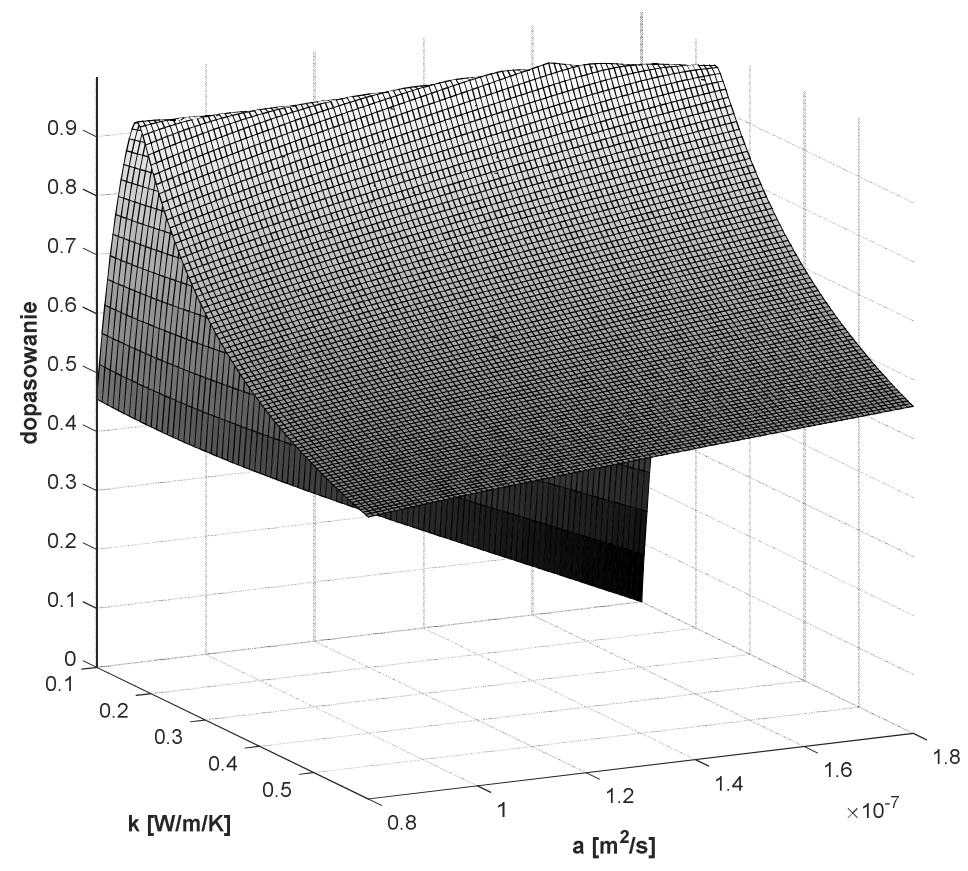

Rys. 2. Wartości funkcji dopasowania dla przyjętego obszaru poszukiwań

Fig. 2. Values of the fitness function for assumed search area

\section{Wyniki}

W celu weryfikacji zaproponowanej procedury rozwiązania zagadnienia odwrotnego wymiany ciepła przyjęto szereg parametrów charakteryzujących doświadczenie, których zrealizowanie byłoby możliwe z praktycznego punktu widzenia podczas rzeczywistego eksperymentu. Obliczenia przeprowadzono dla wartości $k$ oraz $a$ charakteryzujących polistyren wysokoudarowy (ang. HighImpact Polystyrene, HIPS), dla którego $k=0,22 \mathrm{Wm}^{-1} \mathrm{~K}^{-1}, a=1,511 \cdot 10^{-7} \mathrm{~m}^{2} \mathrm{~s}^{-1}$. Zakres poszukiwań zdefiniowano w oparciu o maksymalne i minimalne wartości $k$ i $a$ charakteryzujące typowe tworzywa sztuczne: $k_{\min }=0,1 \mathrm{Wm}^{-1} \mathrm{~K}^{-1}, k_{\max }=0,6$ $\mathrm{Wm}^{-1} \mathrm{~K}^{-1}, a_{\min }=8 \cdot 10^{-8} \mathrm{~m}^{2} \mathrm{~s}^{-1}, a_{\max }=1,8 \cdot 10^{-7} \mathrm{~m}^{2} \mathrm{~s}^{-1}$. Założono ponadto, że próbka ma grubość $d=1 \mathrm{~mm}$, częstotliwość modulacji gęstości strumienia ciepła $f$ wynosi $0,1 \mathrm{~Hz}(\omega=0,6283 \mathrm{rad} / \mathrm{s})$, natomiast jej amplituda $\dot{q}_{\text {Aamp }}=1000 \mathrm{Wm}^{-2}$. Wstawienie powyższych wartości do wzoru (26) pozwoliło obliczyć amplitudę $T_{\mathrm{A}}$ i fazę $\varphi_{\mathrm{T}}$ temperatury zespolonej po stronie ogrzewanej próbki, które równe są odpowiednio $2 \mathrm{~K} \mathrm{i}-0,814 \mathrm{rad}$. Wartości $T_{\mathrm{A}}, \varphi_{\mathrm{T}}, f, d, \dot{q}_{\mathrm{Aamp}}, k_{\min }, k_{\max }, a_{\min }$ oraz $a_{\max }$ posłużyły następnie za dane wejściowe dla optymalizacji algorytmem Waptia.

Optymalizację przeprowadzono przy użyciu populacji liczącej 50 indywiduów, zaś liczbę generacji określono na 100. Prawdopodobieństwo krzyżowania 
było stałe w czasie całej procedury i wynosiło $85 \%$, natomiast prawdopodobieństwo mutacji zmieniało się dynamicznie w zależności od stopnia wzajemnego zróżnicowania osobników. Mutacja była bardziej prawdopodobna, jeżeli zbyt wiele indywiduów posiadało podobny genotyp nie skutkujący pożądaną maksymalizacją funkcji dopasowania. Wybrana opcja planu reprodukcyjnego zakładała, że każdy nowy osobnik zastępował będzie osobnika o najgorszym dopasowaniu z aktualnie istniejącej populacji. Długość genu wybrano w ten sposób, by w procesie optymalizacji brało udział 6 cyfr znaczących wartości $k$ oraz $a$. Powyższe parametry algorytmu uznano za optymalne na podstawie wielokrotnego wykonania obliczeń i obserwacji przebiegu zmienności wartości funkcji dopasowania na przestrzeni pokoleń. Zmniejszenie liczby osobników w populacji skutkowało często sytuacją, w której 100 pokoleń nie wystarczało do osiągnięcia wartości $F$ równej w przybliżeniu jedności, natomiast zwiększenie populacji nie powodowało wyraźnego przyspieszenia konwergencji. Podobne efekty zaobserwowano w przypadku zmniejszania i zwiększania prawdopodobieństwa krzyżowania, przy czym parametr ten nie wpływał praktycznie na czas wykonania algorytmu dla 100 pokoleń, podczas gdy zwiększanie populacji wiązało się z wydłużeniem czasu obliczeń.

Ze względu na inicjalizację algorytmu przy pomocy losowej populacji oraz ogólnie stochastyczny charakter procedury, ścieżka dojścia do rozwiązania, którą ilustruje wartość funkcji dopasowania na przestrzeni pokoleń jest różna przy kolejnych uruchomieniach algorytmu. Wielokrotne wykonanie programu pozwoliło stwierdzić, że po upływie 100 pokoleń procedura osiąga praktycznie jednakowe wartości $k$ i $a$ niezależnie od ścieżki dojścia do rozwiązania. Typowy przebieg wartości funkcji dopasowania na przestrzeni generacji przedstawia rysunek 3 .

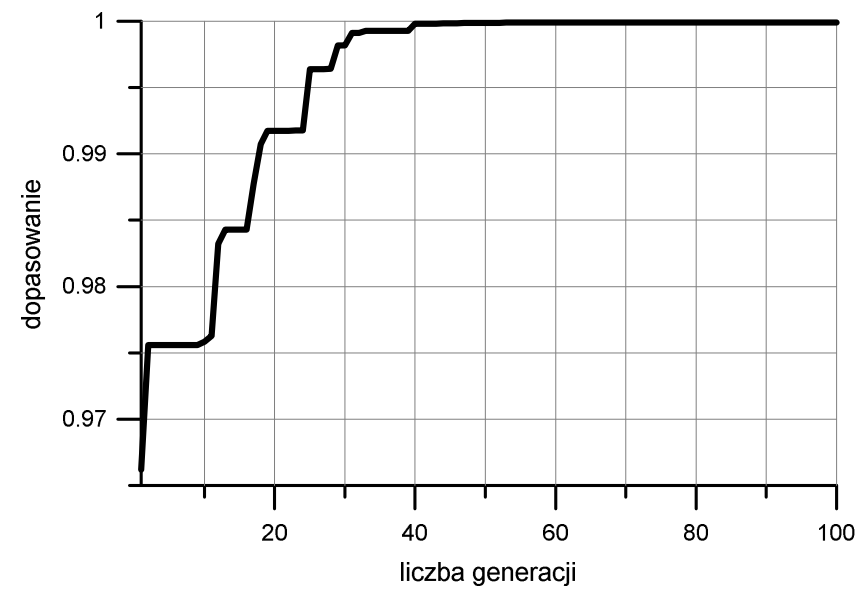

Rys. 3. Wartość funkcji dopasowania w kolejnych generacjach

Fig. 3. Values of the fitness function in successive generations 
$\mathrm{Z}$ rysunku 3 wynika, że algorytm jest $\mathrm{w}$ stanie znaleźć wartości $k$ i $a$, dla których funkcja dopasowania osiąga wartość bliską jedności. Chociaż w zademonstrowanym przykładzie ma to miejsce już ok. czterdziestego pokolenia, zaobserwowano przypadki, w których wymagana liczba generacji wynosi $20 \div 80$. Charakterystyczne jest, że już w pierwszym pokoleniu dopasowanie najlepszego indywiduum w populacji jest bardzo wysokie - wynosi 0,966. Wytłumaczyć to można na podstawie postaci zależności wartości funkcji dopasowania od $k$ i $a$ (rys. 2). Istnieje duże prawdopodobieństwo, że jeden spośród 50 osobników pierwszej - generowanej losowo - populacji pochodził będzie właśnie $\mathrm{z}$ tego rejonu, ponieważ występuje tam stosunkowo rozległy obszar wysokich wartości $F$. Jako wynik otrzymano wartości $k$ i $a$ równe odpowiednio 0,220 $\mathrm{Wm}^{-1} \mathrm{~K}^{-1}$ i $1,512 \mathrm{~m}^{2} \mathrm{~s}^{-1}$. Błąd względny wyznaczenia wartości przewodności cieplnej wyniósł więc $0,025 \%$, natomiast wartość dyfuzyjności cieplnej odtworzona została z błędem równym $0,038 \%$. Jakkolwiek wyniki te wydawać się mogą obiecujące, pamiętać należy, że zostały uzyskane w na podstawie procedury, której dane wejściowe określono na drodze teoretycznej. W rzeczywistości wartości $T_{\mathrm{A}}$ oraz $\varphi_{\mathrm{T}}$ obarczone będą błędami pomiarowymi. Podobnie zadane parametry eksperymentu zrealizować można jedynie ze skończoną dokładnością. Określenie amplitudy modulacji gęstości strumienia ciepła $\dot{q}_{\text {Aamp }} \mathrm{W}$ przypadku zastosowania do tego celu folii grzewczej wymagać będzie pomiaru napięcia i natężenia prądu jej zasilania, natomiast na dokładność wymuszenia częstotliwości oscylacji wpływ może mieć stała czasowa układu ogrzewania.

Z przeprowadzonych obliczeń wnioskować można, że algorytm genetyczny dobrze nadaje się do rozwiązania specyficznej postaci zagadnienia odwrotnego wymiany ciepła scharakteryzowanego w punkcie 2.1 i opisanego równaniem (26). Kwestią otwartą pozostaje natomiast, czy zaproponowana konfiguracja doświadczalna i przyjęte założenia sprawdzą się w warunkach rzeczywistego eksperymentu. Szczególnie przydatne byłoby w przyszłości przeprowadzenie analizy czułości rozwiązania na błędy pomiarowe amplitudy $T_{\mathrm{A}}$ oraz fazy $\varphi_{\mathrm{T}}$ temperatury zespolonej.

\section{Podsumowanie}

$\mathrm{W}$ artykule zaprezentowano koncepcję równoczesnego pomiaru wartości przewodności cieplnej $k$ i dyfuzyjności cieplnej $a$ materiału wraz z procedurą pozwalającą na otrzymanie wyników na drodze dwuparametrowej optymalizacji wykorzystującej algorytm genetyczny. Metoda charakteryzuje się prostą konfiguracją eksperymentalną i założeniami łatwymi do realizacji w warunkach praktycznych. Przy założeniu, że możliwe jest wymuszenie oscylacji gęstości strumienia ciepła o dokładnie znanej amplitudzie $\dot{q}_{\text {Aamp }}$ i częstotliwości kątowej $\omega$, konieczny jest pomiar jedynie amplitudy $T_{\mathrm{A}} \mathrm{i}$ fazy $\varphi_{\mathrm{T}}$ oscylacji temperatury.

Zaproponowana procedura obliczeniowa pozwala na szybkie i dokładne znalezienie właściwości cieplnych badanego materiału na podstawie stosunkowo 
niewielkiej ilości danych wejściowych. Optymalizacja przy użyciu algorytmu genetycznego jest $\mathrm{w}$ stanie $\mathrm{z}$ powodzeniem odtworzyć wartość dyfuzyjności cieplnej, pomimo niezbyt wyraźnego maksimum zależności wartości funkcji dopasowania od wartości $a$. Dalszy rozwój metody obejmować powinien analizę czułości otrzymywanych wyników na błędy pomiarowe poszczególnych wielkości, a następnie weryfikację w warunkach eksperymentalnych.

\section{Literatura}

[1] Parker J., Jenkins R.J., Butler C.P., Abbott G.L.: Flash method of determining thermal diffusivity, heat capacity, and thermal conductivity, J. Appl. Physics, 32 (1961) 1679-1684.

[2] Vozár L., Hohenauer W.: Flash method of measuring the thermal diffusivity. A review, High Temp. - High Pressures, 35/36 (2004) 253-264.

[3] Gustafsson S.E., Karawacki E., Khan M.N.: Transient hot-strip method for simultaneously measuring thermal conductivity and thermal diffusivity of solids and fluids, J. Physics D: Appl. Physics, 12 (1979) 1411-1421.

[4] Gustafsson S.E.: Transient plane source techniques for thermal conductivity and thermal diffusivity measurements of solid materials, Rev. Sci. Instruments, 62 (1991) 797-804.

[5] Krupa P., Malinarič S.: Using the Transient plane source method for measuring thermal parameters of electroceramics, Int. J. Math., Comput., Statistical, Natural Phys. Eng., 8 (2014) 733-738.

[6] ISO 22007-2:2015, Plastics - Determination of thermal conductivity and thermal diffusivity - Part 2: Transient plane heat source (hot disc) method.

[7] Hisano K., Sawai S., Morimoto K.: Conventional simultaneous measurement of specific heat capacity and thermal conductivity by thermal radiation calorimetry, Int. J. Thermophysics, 19 (1998) 291-304.

[8] Reading M., Hourston D.J.: Modulated temperature differential scanning calorimetry. Theoretical and practical applications in polymer characterisation, Springer, Dordrecht, 2006.

[9] Marcus S.M., Blaine R.L.: Thermal conductivity of polymers, glasses and ceramics by modulated DSC, Thermochimica Acta, 243 (1994) 231-239.

[10] Raudenský M., Horský J., Krejsa J., Slama L.: Usage of artificial intelligence methods on inverse problems for estimation of material parameters, Int. J. Numerical Meth. Heat Fluid Flow, 6 (1996) 19-29.

[11] Liu G.R., Lee J.H., Patera A.T., Yang Z.L., Lam K.Y.: Inverse identification of thermal parameters using reduced-basis method, Comp. Meth. Appl. Mech. Eng., 194 (2005) 3090-3107.

[12] Vakili S., Gadala M.S.: Effectiveness and efficiency of particle swarm optimization technique in inverse heat conduction analysis, Num. Heat Transfer, Part B: Fundamentals, 56 (2009) 119-141.

[13] Bai D.: Evaluation system for effective thermophysical properties of anisotropic composite material, Aerospace Sci. Technol., 30 (2013) 94-101. 
[14] Adili A., Lachheb M., Kerkeni C., Ben Nasrallah S.: Simultaneous estimation of the thermophysical properties of liquids and of the boundary conditions, Int. J. Thermal Sci., 68 (2013) 53-62.

[15] Gosselin L., Tye-Gingras M., Mathieu-Potvin F.: Review of utilization of genetic algorithms in heat transfer problems, Int. J. Heat Mass Transfer, 52 (2009) 21692188.

[16] Garcia S., Guynn J., Scott E.P.: Use of genetic algorithms in thermal property estimation: Part II - Simultaneous estimation of thermal properties, Num. Heat Transfer, Part A: Applications, 33 (1998) 149-168.

[17] Divo E., Kassab A., Rodriguez F.: Characterization of space dependent thermal conductivity with a BEM-based genetic algorithm, Num. Heat Transfer, Part A: Applications, 37 (2000) 845-875.

[18] Jones M.R., Tezuka A., Yamada Y.: Thermal tomographic detection of inhomogeneities, J. Heat Transfer, 117 (1995) 969-975.

[19] He H., He C., Chen G.: Inverse determination of temperature-dependent thermophysical parameters using multi objective optimization methods, Int. J. Heat Mass Transfer, 85 (2015) 694-702.

[20] Raudenský M., Woodbury K.A., Kral J., Brezina T.: Genetic algorithm in solution of inverse heat conduction problems, Num. Heat Transfer, Part B: Fundamentals, 28 (1995) 293-306.

[21] Vasileiou A., Vosniakos G-C., Pantelis D.: Determination of local heat transfer coefficients in precision castings by genetic optimisation aided by numerical simulation, Proc. Inst. Mech. Eng., Part C: J. Mech. Eng. Sci., 229 (2014) 735-750.

[22] Vakili S., Gadala M.S.: Low cost surrogate model based evolutionary optimization solvers for inverse heat conduction problem, Int. J. Heat Mass Transfer, 56 (2013) 263-273.

[23] Liu F-B.: An application of particle swarm optimization to identify the temperature-dependent heat capacity, Heat Mass Transfer, 48 (2012) 99-107.

[24] Liu F-B.: Inverse estimation of wall heat flux by using particle swarm optimization algorithm with Gaussian mutation, Int. J. Thermal Sci., 54 (2012) 62-69.

[25] Wandelt M., Roetzel W.: Lockin thermography as a measurement technique in heat transfer, QIRT 96 - Eurotherm Series 50 - Edizioni ETS, Pisa, 1997.

[26] Zheng G.R., Yang S.C.: Solution of steady periodic heat conduction by the finiteelement method, Num. Heat Transfer, Part A: Applications: Int. J. of Comp. Methodology, 15 (1989) 525-534.

[27] Gołębiowski W.: https://lavag.org/files/file/94-waptia-genetic-optimizationalgorithm/ [dostęp: 17 sierpnia 2015 r.].

[28] Charbonneau P.: Genetic algorithms in astronomy and astrophysics, The Astrophysical J. (Supplements), 101 (1995) 309-334. 


\section{APPLICATION OF COMPUTATIONAL INTELLIGENCE ALGORITHMS} FOR DETERMINING THERMAL PROPERTIES OF MATERIALS

\section{S u m m a r y}

This paper presents the principle of simultaneous measurement of thermal conductivity $k$ and thermal diffusivity $a$ in steady-periodic state with application of computational intelligence algorithm to solve an inverse problem. Measurement in steady-periodic state being a special case of transient heat transfer allows for taking into account the heat accumulation phenomena. Furthermore, the determination of time-dependent value of temperature is possible based on the two parameters: amplitude $T_{A}$ and phase angle $\varphi_{\mathrm{T}}$ of oscillations of temperature signal. The analysis of one-dimensional heat conduction in steady-periodic state allows to obtain the relationship between $T_{\mathrm{A}}$ and $\varphi_{\mathrm{T}}$, and the values of thermal conductivity $k$ and thermal diffusivity $a$. The procedure proved to be suitable for accurate estimation of the values of thermal conductivity and thermal diffusivity in less than 100 generations of genetic algorithm with population of 50 individuals. Simple experimental configuration and relatively low sensitivity of the directly measured values to systematic errors are the advantages of proposed method. However, the experimental verification is required to assess its practical usefulness.

Keywords: thermal measurements, thermal conductivity, thermal diffusivity, optimisation, genetic algorithm, steady-periodic state

DOI: $10.7862 / \mathrm{rm} .2016 .2$

Otrzymano/received: $19.10 .2015 \mathrm{r}$.

Zaakceptowano/accepted: 21.03.2016 r. 